\title{
The IWMA and Industrial Conflict in England and France
}

\author{
Iorwerth Prothero
}

The International Working Men's Association (IWMA) was established by groups in London and Paris as a radical association expressing a familiar radical internationalism and asserting both the importance of peace, international harmony and national liberation to working people and the importance of working people in achieving these goals. In the former city it continued an ongoing phenomenon of radical associations embracing both Londoners and foreigners, ${ }^{1}$ and operated as one of several overlapping openly radical associations, whereas the different political regime in France led the group in Paris to operate much more cautiously and avoid such overt politics (see figure 4.1). Nevertheless it was because of its radical political nature that the London Society of Compositors rescinded its original decision to send a delegate to the first conference in Geneva. ${ }^{2}$ Yet the IWMA also included trade union figures of national importance and reputation and sought trade union support, and for a while its main activity was the co-ordination of international action in support of strikes in England and France. This aspect of the IWMA should be related to the nature of trade unionism at the time.

Trade unionism took different forms, and we need to identify three distinct kinds of industrial action. ${ }^{3}$ The workplace was a site of social relations, involving informal hierarchies, privileges, rights, conventions, customs and roles, and most work-related conflicts were confined to single workplaces in response to behaviour and actions that transgressed established ways, including changes in work organization, and involved no formal organization. In addition, secondly, there were also more formal supra-workplace organizations, and societies and clubs consisting of workingmen in the same trade (corps de métier) had for a long time been important elements in the world of

1 Iorwerth Prothero, "Chartists and foreign political refugees", in Sabine Freitag (ed), Exiles from European Revolutions. Refugees in Mid-Victorian England (Oxford, 2003), pp. 209-233.

2 Modern Records Centre, University of Warwick [hereafter, MRC], London Compositors' Society MS $28 / \mathrm{CO} / 1 / 8 / 9 / 1$.

3 There is a full discussion of these points in Iorwerth Prothero, Radical Artisans in England and France, $1830-1870$ (Cambridge, 1997), Chs 3-4.

(C) IORWERTH PROTHERO, 2018 | DOI 10.1163/9789004335462_005

This is an open access chapter distributed under the terms of the prevailing CC-BY-NC License. 9789004335462 
labour in Britain and France. They varied in both form and in functions, such as benefits, placement, tramping, arbitration, negotiation, and sociability, usually embraced a minority of their trade and were generally small. They often came into conflict with particular masters but also often expressed the internal hierarchies, rifts and conflicts that characterized the workforce. Trade societies were thus rivals and tended to oppose other societies in the same trade, often seeking to corner employment in workshops exclusively for their own members. This could make co-operation and united action among rival trade societies very difficult, so that it tended to be easier on non-work issues, such as politics, or questions of general importance to the world of labour, such as the legality of workingmen's societies or strikes.

There was, however, a third aspect of trade unionism, in the form of combinations for improvements on a much wider scale than individual trade societies. Whereas societies in the same trade were rivals and usually hostile to one another on questions of placement, closed shops or demarcation, they might unite with one another on certain issues that concerned and would benefit them all. Thus it was well established for artisan and building trades and some newer skilled trades (such as engineering) to take advantage of favourable situations to make general demands on which they all could unite, usually over pay but sometimes hours or certain issues specific to the trade. Such combinations involved members of rival societies and also men in no society at all in a temporary alliance for a specific goal which ended after the success or failure of the movement. The demands usually met resistance from the employers and often led to large strikes. These combinations were not led by trade societies, although sometimes existing benefit societies did start a special fund to be drawn on if the combination resulted in a strike. More often a combination created a new organization meant only to last until the specific issue was settled, such as ostensible benefit societies, temporary "united" and "consolidated" orders or societies in England and sociétés de résistance in France, the leaders of which were often not active in any permanent trade organization and were frequently radicals. These combinations tended to take place in waves at similar times of economic recovery in England and France and often aroused great alarm among propertied classes and even "moral panics" in the belief that they were motivated by dangerous new socialist or republican ideas and directed by sinister, subversive organizations.

Trades on strike might receive help from other trades in the same area or from members of the same trade in other areas, but some disputes involved a particularly wide degree of support, not usually because of the size or intrinsic importance of the combination but because of the means used to break it. These included employers' lock-outs, imposition of the "document" (a signed 
renunciation of labour organization), or refusal to employ anyone unless he provided a "discharge note", "quittance paper" or livret signed by his previous employer; they also included measures by government or other authorities such as arresting strikers, refusing relief to strikers' families or providing government workmen as strike-breakers. These abuses of power by employers and partisan actions by authorities aroused great emotion, broadened industrial conflicts, and often radicalized them. While radicals and socialists seeking working-class support tended to regard trade and benefit societies as laudable organizations of the poor and possible bases for support, they were not usually so happy about backing workers in wage disputes. They were much readier to condemn repression of strikes and combinations by the authorities, and even abuses of authority by employers. ${ }^{4}$ It was also this same aspect that was most likely to arouse wider trade union protest. Thus Paris trades and radicals rallied in support of the great carpenters' strike of 1845 for a uniform daily rate when the authorities arrested strikers, raided two trade clubs and seized their funds, refused passports to striking carpenters wishing to leave Paris on tramp, and supplied military carpenters to work for the masters. This had an important effect on labour politics in Paris in 1848. In 1859 a movement in the London building trades was met by the employers with a general lock-out which provoked a huge campaign of support for the men among the trades and the radical clubs; it was as radicals that Cremer (carpenter) and the ex-Chartists Howell (bricklayer) and Odger (shoemaker), all later leading members of the IWMA, became prominent in the campaign and then in trade unionism.

Under the authoritarian Second Empire radical and trade union action in France was dangerous, but there was some relaxation in the 186os as the regime tried to channel working-class activity in non-political social welfare directions to detach it from republicanism, and these provided some limited openings for action. Since benefit societies (sociétés de secours mutuels) were encouraged, trade societies often took this form. As a Paris compositors' society told their London brethren, "they had previously been obliged to have their Society enrolled as a Benevolent Institution only - as any society for the maintenance of wages is not tolerated by the laws of France." When they prepared a combination for higher wages they established a separate secret fund. ${ }^{5}$ When the regime allowed and encouraged co-operative societies these could also provide a haven for trade unionists and radicals, as they had under the Second Republic. At the first IWMA conference:

4 Ibid., pp. 109-111, 162-165, 309.

5 MRC, London Society of Compositors, 58 th. Quarterly Report (Aug. 1862), MS 28/CO/1/8/7/1, fos $45^{-47,} 55^{-57}$. 
Citizen Tolain said that in Britain, thanks to the genius of British liberty, the class movement manifested itself by a policy of resistance, whereas in France by reason of the shackles imposed upon the organization of the working classes, a strike has only been a rare and extreme measure and co-operation has been there deemed to be the only means of working class emancipation. ${ }^{6}$

Plebeian radical mobilization was successful through building on existing social relationships, shared structures of communication, and community ties built up by routine interaction and conversation. Taverns, cabarets, pubs, cafes, coffee-houses, dance-halls and chapels were all important channels of such sociability and sites of neighbourhood social clubs, but so were workshops and trade clubs (which usually met in cafes and pubs). Thus workplaces and trades formed vital bases for wider movements, including political mobilization, and plebeian radicals in both countries therefore often sought and gained the support of occupational groups, as members and as participants in demonstrations. In London in the 186 os trade union support was gained by the over-lapping National League for Polish Independence, Working Men's Garibaldi Committee and, especially, Reform League. It was generally recognized that trade union support was essential to a successful popular movement in the capital. When a meeting to set up a new radical association in 1864 was not a success Holyoake attributed this to a failure to canvass the trades, while Marx recognized that "without the TRADES UNIONS no MASS MEETING is possible."7 It was therefore inevitable that when the IWMA was founded in London it would seek and gain trade union support there. ${ }^{8}$ The Paris section of the IWMA similarly sought support from trade societies in the city and gained enough financial contributions from them to send delegates to the IWMA conference at Geneva. A few trades even affiliated, notably the bronze workers and bookbinders. ${ }^{9}$

Although at the time of the foundation of the IWMA there were suggestions that an international association could stop blacklegs coming from abroad, this was not emphasized or envisaged as the main activity. ${ }^{10}$ But the

$6 \quad$ Working Man 25 May 1867 , p. 9.

$7 \quad$ English Leader 9 July 1864, p. 4; Marx to Engels, 1 Feb. 1865, in Karl Marx and Friedrich Engels, Collected Works (London, 1987), 62, p. 74.

8 E.g. Bee-Hive 29 April 1865, p. 1; Commonwealth 8 Sept. 1866, p. 8; Working Man 10 Aug. 1867, p. 9 .

9 Archives de la Préfecture de Police, Paris [hereafter, APP], Internationale à Paris, Ba 439, 4812 .

$10 \quad$ Bee-Hive 5 Dec. 1863, p. 1; Michel Cordillot, Aux Origines du Socialisme Moderne. La Première Internationale, la Commune de Paris, l'Exil (Paris, 2010), p. 33; Julian P. Archer, The First International in France, 1864-1872 (Lanham, New York and Oxford, 1997), p. 23; Knud 
favourable economic situation in the mid-186os and the legalization of strikes in France in 1864 meant that the formation and growth of the IWMA coincided in both countries with waves of combinations of unprecedented scale. Given its membership it could not be unaffected and became for a while involved in mobilizing international support for strikes and preventing the importation of strike-breakers from the Continent into England.

The IWMA, in fact, did not initiate these practices. On the Continent there were links between trade societies that crossed national boundaries, fortified by migrant workers, especially through the artisan practices of tramping along established networks and receiving help from local clubs. ${ }^{11}$ In the 185 os there were attempts at bilingual trade journals, such as the printers' Guthenburg and shoemakers' Innovator/Innovateur. In $185^{2}$ the London Society of Compositors sent help to the Paris Typographical Society. London was also the main destination of continental political refugees, the greatest component being French, including a number of working men. ${ }^{12}$ The Paris compositor Louis Vasbenter was an associate of Proudhon under the Second Republic until he fled to London, where he was able to find work at his trade and be admitted to the compositors' society. He acted as interpreter when in 1862 two delegates came from the Paris compositors, and the London society again agreed to send funds to help their general strike. ${ }^{13}$ In 1864 the Limoges potters struck and appealed to the Staffordshire potters for support, and through the efforts of the political exile Talandier their case was taken up by the radical and pro-trade union newspaper the Bee-Hive and the London Trades' Council. ${ }^{14}$

Moreover the recruiting of foreign blackleg labour was also established practice in England, such as during the strikes of tin-plate workers in Wolverhampton in 1851 and Birmingham in 1853, and in London among tailors and pianoforte-makers in 1850, gas-stokers in 1859 , and bakers in 1872 , as well as the cigar-makers..$^{15}$ As a result there were attempts to counter this practice.

Knudsen, "The strike history of the First International", in Fritz Van Holthoon and Marcel van der Linden (eds), Internationalism in the Labour Movement 1830-1940 (Leiden, 1988), p. 309 .

11 Prothero, Radical Artisans, pp. 55-56.

12 Sylvie Aprile, Le siècle des exilés. Bannis et proscrits de 1789 à la Commune (Paris, 2010), pp. 107-112, 122-124.

13 MRC, London Society of Compositors, Quarterly Reports, 16th. (22 May 1852), 18th. (7 July 1852), 58th. (Aug. 1862, fos.41-63), 59th. (Oct. 1862, fos 15-16), MSS 28/CO/1/8/3, 1/8/7/1, 8.

14 Bee-Hive 18 June 1864, p. 4; 25 June 1864, p. 5; 16 July, p. 5; 23 July, p. 7.

15 Trades' Advocate and Herald of Progress 12 Oct. 1850, p. 127; Reynolds's Newspaper 3 Aug. 1851, p. 6, 10 Aug., p. 14; People's Paper 12 May 1855, p. 4; Times 28 March 1861, p. 10; 10 April, p. 11; Workman 5 July 1861, p. 2; Tichborne News 6 July 1872, p. 3 . 
The London type-founders struck in $185^{\circ}$ and wrote to the founders' club in Paris to try to prevent French workmen coming to replace them, and the Paris society circularized all type-foundries in France, Germany, Belgium, Netherlands and Switzerland to this end. ${ }^{16}$ During the great London builders' strike of 1859 "the employers threatened to import foreign workmen in mass. The English workmen immediately wrote to all the foreign working men's associations," but their failure to stop foreign blacklegs led to the defeat of the strike, ${ }^{17}$ although some Paris building workers did send help. ${ }^{18}$ In Paris in $1864-569$ trades chose the best time to present demands and strike, and the London hatters and saddlers sent aid to their fellow trades. ${ }^{19}$

The composition of the IWMA in London meant it was drawn in, and some trades affiliated during disputes, such as pattern-drawers and basket-makers. But it was not involved in the Limoges and Paris disputes of 1864-5, and the turning-point, as is well known, was its support for the London tailors' strike of 1866. The London tailors had launched combinations in the mid-1830s and mid-1840s to raise wages and check homework, in both cases radicals playing a leading role, Chartists on the latter occasion forming a national union. ${ }^{20}$ Tailors' combinations in British and Continental towns were nearly always in April at the start of the brisk season, the time of "that spirit of independence amounting pretty nearly to defiance, - which inspires our class at this season, and prepares them for anything."21 Tailors' clubs tried to enforce a uniform agreed stint or "log", a list of the times it would take a skilled workman to work different articles. The log could then act as the basis for calculating a man's pay at a uniform hourly rate. In the mid-186os there were new tailors' combinations, the provincial tailors coming together in an Amalgamated Tailors' Association, while the skilled tailors in the bespoke shops of London's West End formed their own London Operative Tailors' Protection Association, with an executive composed entirely of radicals, including the former Chartist

$16 \quad$ Red Republican 17 Aug. 1850, pp. 65-67.

17 Working Man 25 May 1867, pp. 9-10.

18 Cremer, Odger, Bee-Hive 16 July 1864, p. 5 .

19 Prefect of Police to Minister of the Interior, 26 Jan. 1866, Archives Nationales, Paris [hereafter, AN ], Rouher Papers, 45 AP 6, 3; Jean Vial, La Coutume chapelière. Histoire du mouvement ouvrier dans la chapellerie (Paris, 1941), p. 169.

T.M. Parssinen and I.J. Prothero, "The London tailors' strike of 1834 and the collapse of the Grand National Consolidated Trades' Union: a police spy's report", International Review of Social History, 22 (1977), pp. 65-107; I.J. Prothero, "London Chartism and the trades", Economic History Review 24 (1971), pp. 212-213.

21 Tailor 6 April 1867, p. 406; Iorwerth Prothero, Artisans and Politics in Early NineteenthCentury London. John Gast and his Times (Folkestone, 1979; Abingdon, 2013), p. 301. 
Peter Henriette. In April 1866 they presented their demands for a uniform log for good quality work and a rise of a penny an hour in the time rate used for calculating pay. The masters responded with a refusal and a general lock-out. This was just the sort of action that would provoke wider support for a strike, because the dispute "was not simply a question of wages, but one of better treatment towards the men."22 Thus provincial tailors rallied to the support of London, as did the IWMA. In such London disputes it was normal for the masters to secure blacklegs in Germany, but in this case, while the Amalgamated Tailors prevented recruitment in the country, the IWMA helped prevent it in Hamburg and Berlin, "thus stopping the usual resources of the employers." Aid also came from the Paris tailors. The London masters quickly gave in and conceded a penny-an-hour rise. ${ }^{23}$

This victory had a tremendous impact and new branches were formed of the Amalgamated Tailors in the provinces and London Operative Tailors in the Home Counties. But it also raised the prestige of the IWMA and the value of its international contacts in industrial conflicts. It gained trade society, trades' council and TUC support, and members later looked back on the IWMA as an organization established by and for trade unions. ${ }^{24}$ Some, like the carpenters' leader Robert Applegarth even saw its role as an educational one, promoting British ways, labour organization and liberty by encouraging the formation and spread of trade unions in Europe which would moreover raise wages and reduce both the pool of cheap blackleg labour and the cheap goods competing with British production. Odger rejoiced that "on the continent they are raising up trade societies on the model of our English ones." 25

The Paris section then went on to establish chambres syndicales, trade committees to organize workers for collective bargaining and negotiation, which were now tolerated by the government. ${ }^{26}$ The turning-point here was the strike

22 Lawrence, Bee-Hive 21 April 1866, p. 5.

23 Workman's Advocate 23 Dec. 1865, p. 5; Commonwealth 10 Feb. 1866; p. 6; 31 March, p . 6; 7 April, pp. 4,6; 14 April, p. 6; 28 April, p. 6; Bee-Hive 28 April 1866, p. 5; Working Man 1 May 1866, p. 7; Tailor 8 June 1866, p. 128.

24 Commonwealth 8 Sept. 1866, p. 8; APP, Internationale, Ba 439, 1172; Henry Collins and Chimen Abramsky, Karl Marx and the British Labour Movement. Years of the First International (London, 1965); Knudsen, "Strike history", p. 311.

25 Applegarth, Times 15 Sept. 1869; Odger, Commonwealth 2 June 1866, p. 6; Cremer, Working Man, 25 May 1867, pp. 9-10; Jung, Amalgamated Society of Carpenters and Joiners'Monthly Report July 1869, p. 149; Collins and Abramsky, Karl Marx, p. 91.

26 Varlin, Mutualité 15 Oct. 1866, p. 324; Varlin, Marseillaise 20 April 1870, p. 2; Albert Richard, « Les Débuts du Parti Socialiste Français », Revue Politique et Parlementaire 11 (1897), p. 69; Jacques Rougerie, "Sur l'histoire de la Première Internationale", Le Mouvement Social no. $5^{1}$ (1965), p. 37. 
early in 1867 of the Paris bronze-workers, a strongly organized trade affiliated to the IWMA. The employers tried to crush them by a lock-out, which made the dispute the sort likely to arouse wider support, and aid came from other Paris trades, from the provinces, and also from London through the agency of the IWMA. The consequent rumours of inexhaustible English funds led the masters to give in. ${ }^{27}$ Meanwhile the Paris tailors, encouraged by the triumph in London the previous year, formed their own combination for a uniform log, in preparation for which they formed a benefit society to collect subscriptions for a fund, and a strike followed in 1867, again in April..28

During the London tailors' strike and lock-out in 1866 the West-end employers had managed to have some work done for them in other sectors of the industry by struggling small masters desperate for orders and journeymen working at home, for whom these new better-paid orders were "quite a little harvest for them." After the strike the London Society sought to prevent this happening again during a future attempt to gain a log, and therefore opened new branches around London and even in Brighton to check work being done there for London firms, and made great efforts to organize outworkers in London, including women and East European Jews. As part of this strategy they also affiliated to the IWMA and strengthened contacts with the Paris tailors in the hope of checking foreign blacklegs. ${ }^{29}$ When the Paris tailors' strike occurred the London tailors acted to stop work being done in London for Paris masters and also sent their president and secretary over to Paris to conclude a formal alliance with the Paris tailors for mutual support. The Paris strike succeeded and the men gained a ten per cent rise and pay for basting, and this success was widely attributed to extensive English support - there were rumours that English tailors had sent 200,000 francs. The London tailors then called a new general strike for a log, in April as ever, and they in turn now received help from tailors in Paris and other towns in France, while the IWMA raised funds on the Continent and America. ${ }^{30}$

27 Commonwealth 9 March 1867, p. 1; 6 April, p. 1; Working Man 6 April 1867, p. 3; Cordillot, Aux Origines, pp. 36-42; Archer, First International, pp. 82-83; Knudsen, "Strike history", p. 313 .

28 Working Man 1 March 1867, pp. 5-7; 6 April, p. 3; Commonwealth 9 March 1867, p. 4; 29 June, p. 4; Tailor 20 April 1867; Operative Bricklayers' Society, Annual Report 1866-7, p. 63; MRC MS 78/OB/4/2; Webb Collection of Trade Union Manuscripts, Library of Political and Economic Science, London School of Economics, A 11, fo 51; Keszler, Des grèves, à propos de celle des ouvriers tailleurs en avril 1867 (Paris, 1867) p. 47.

29 Tailor 8 June 1866, p. 128; 16 Feb. 1867.

30 AN, Graces, Bв 24720 , Feb.-March 1868; Tailor 1June 1867, p. 110;13July, p. 194; 20 July, p. 209; Commonwealth 13 April 1867, p. 4; 4 May, p. 5; 8 June, p. 5; Working Man 13 July 1867, p. 7 . 
The successes of the Paris tailors and bronze-workers confirmed the possibilities of help from across the Channel and gave the French IWMA great prestige. Trade societies joined, membership shot up, and the Paris branch went on to issue appeals in support of other groups on strike. When in 1868 the Genevan building workers struck the IWMA committee in Paris, the leading figure in which was by now the bookbinder Varlin, prevented the recruitment of blacklegs and in two weeks raised 10,000 francs among the Paris trades, which saved the strike from defeat. ${ }^{31}$ But the committee was now prosecuted and imprisoned and the IWMA was crushed in France. Moreover, in England, despite the help from abroad through the IWMA, and the outrage among trade unionists and radicals at the arrest of peaceful picketers, the London tailors' strike of April 1867 was defeated and their temporary combination ended. ${ }^{32}$ In 1868 British trade union affiliation to the IWMA also fell, although they still responded to appeals for aid. ${ }^{33}$

The IWMA did revive in France 1869 under the leadership of Varlin, Malon, Richard and Aubry as a small, radical organization, but then gained a new importance through the great wave of combinations and strikes all over the country in 1869 and 1870 . In many of them members of the IWMA took leading roles and the IWMA was swept along and developed systematic aid. Encouraged by exaggerated and unrealistic hopes of support from England, combinations and trade societies gave their adherence to the IWMA, some resistance societies joining just before they went on strike, although it is not clear what their membership amounted to. The Paris leather-dressers' strike of July to December 1869 aroused particular support among Paris trades and radicals because of the masters' use of the document, and the ever-active Varlin managed to group them in a Federal Committee of Working Men's Societies, officially separate from the IWMA but with the same leaders and using the same premises. Similar federations were formed in Lyons and Marseilles, and in the increasingly extreme wave of radical public meetings in Paris the speakers condemned the collusion between government and employers against strikes. ${ }^{34} \mathrm{~A}$ panic developed, encouraged by the regime, in which the hand of the IWMA was seen in every strike. In truth the strike wave was not initiated or led by the IWMA, rather the strikers pushed the IWMA. ${ }^{35}$

31 Archer, First International, pp. 113-114.

32 Tailor 27 April 1867, pp. 41-42; 4 May, p. 54; 1 June, p. 110; Working Man 4 May 1867, pp. 4-6.

33 Collins and Abramsky, Karl Marx, p. 173.

34 Alain Dalotel, Alain Faure and Jean-Claude Freiermuth, Aux origines de la Commune. Le mouvement des réunions publiques à Paris 1868-1870 (Paris, 1980), pp. 264-269.

Archer, First International, pp. 151-166, 197-203, 207, 211-223. 
In the process the policy on strikes changed. Up to 1868 the IWMA gave support not to simple strikes for higher wages but in the sort of conflicts that would anyway have provoked wider aid among the trades, notably when lockouts were imposed on the London tailors, Paris bronze-workers and Genevan building workers. The Paris bronze-workers were engaged in a number of disputes and strikes from 1864, but it was only with the lock-out in 1867 that the other trades and the IWMA rallied to their support. At the time of the Roubaix spinners' strike in 1867 against employers' regulations and machinery the Paris section of the IWMA confined itself to condemnation of the oppressive regulations, police actions against the strikes and the workers' machinewrecking. ${ }^{36}$ It did not support the many efforts at the time to improve wages or hours, such as the tailors' strike and the building trades' combination in Paris in 1867 . While in $1869-70$ it continued to be involved as before when there were lock-outs, such as of the Basle ribbon-weavers, or attacks on strikers by police or troops, such as at Charleroi, Seraing. St.-Etienne and St. Aubin, the situation had changed. Up to 1868 strikes had tended to be offensive ones among the more skilled artisan, building and engineering trades for improvements, but from 1868 the worsening economic situation provoked food riots, machine-wrecking and defensive strikes among less skilled industrial workers, especially in mining and textiles, which were more spontaneous, poorly organized and more violent. There was a greater readiness to support strikes against reductions than those for rises. and as branches in the provinces and Paris were swept along they moved to a blanket support for all strikes, most of which failed..$^{37}$

The extent of the adherence of the French strikers to the IWMA and of its own independent strength is doubtful, especially after arrests in April and May in Paris and Lyons removed its leadership. This opened the way to dominance by the Blanquists, who, sensing the imminent fall of the Empire after the Victor Noir protests, had started joining the IWMA sections. Their concern for revolution left little interest in trade unions or the Paris trades' Federal Committee, which were moreover badly disrupted by the war, and so the involvement of the IWMA in trade unionism in France ended. ${ }^{38}$ At the same time the IWMA in London also lost its trade union element as the inability of Continental workers' societies to prevent strike breakers coming to London became clear, ${ }^{39}$

$36 \quad$ Working Man 6 April 1867, pp. 4-5; Archer, First International, pp. 84-85.

37 Archer, First International, pp. 84-85, 142, 152, 202; Knudsen, "Strike history", pp. 313-315; Michelle Perrot, Les ouvriers en grève en France 1871-189o (Paris,1974), pp. 77-78.

38 APP Ba 439, Blanquistes, ff. 9-19; Archer, First International, pp. 209-210, 246-248.

39 APP, Internationale, Ba 435, 1172. 
and its basis thenceforth increasingly lay in the metropolitan ultra-radical republican clubs and societies.

The IWMA had begun in England and France as a political organization, although the nature of the Second Empire meant that in France its politics had to be concealed and activities were channelled into fields that were or became allowed, such as club, education, benefit society, Exhibition delegations, elections, co-operation and trade organizations. In its early years the IWMA was small, weak and little known, but its survival came through support for strikes, whereby it achieved an important, if temporary juncture between political radicalism and trade unionism. Since this came through building on and furthering established practices, such as radical mobilization through workplaces and trade clubs, wider trade combinations, occasional support for these among other workers on particular kinds of issue, and trans-national support and aid, it is continuity that is most apparent. Nevertheless, it was original in creating a permanent international labour organization that mobilized international support for strikes and widened the range of strikes that were supported. In 1867 it achieved a peak in membership, importance and notoriety, when it secured support from trade unions hoping in England to prevent strike-breakers from the Continent and in France to receive extensive English financial aid. As the former did not materialize English trade union affiliation fell away. In France it was the strikes of 1869-70 that revived the IWMA from near-extinction and moved it into a blanket support for all types of strike, but this was in an unfavourable economic situation. Strikes did not succeed, the unrealistic hopes of English wealth could not be met and the General Council in London, overwhelmed by the volume of appeals, reacted against the rash and ill prepared strikes. While success in strikes caused the rise of the IWMA, failures led to its decline. 


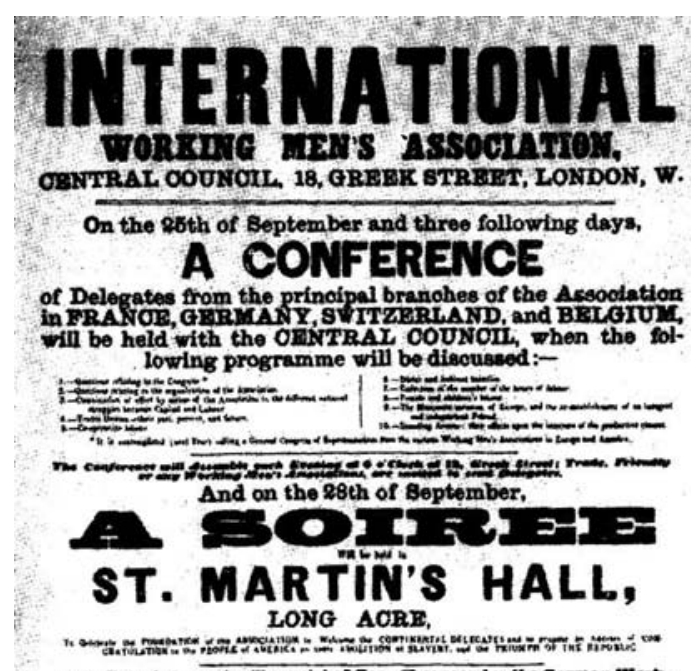

The Eatertalnmont will coneist of Tos, Goorabes by the Gorman WortInt Ben's Choral Boelety. Operatio and otber woicotions by the Band

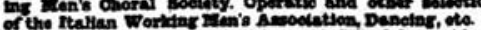

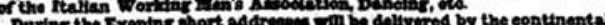
Daring the

Tioket to admit at half-past 7, inoluding Tea, Conoert, Addresses and Danoing, One Shilling.

Tiokets to admit after Tes at half-past 8, to Conoert, Addreases and Danoing, six-penoe.

DANOING AT HALF-PABT THN.

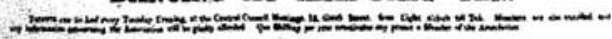

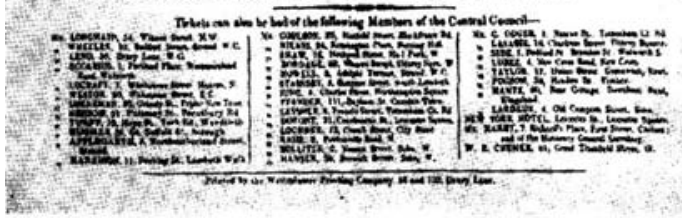

FIGURE 4.1

IWMA poster for a conference on $25-28$ September, 1865 , i.e. exactly one year after the foundation meeting, which had taken place in the same place, in St Martin's Hall, Long Acre.

PRIVATE COLLECTION. 